\title{
A New Theme in Mathematics Curriculums: Financial Literacy
}

\author{
Abdullah Ozkale, Emel Ozdemir Erdogan \\ Suleyman Demirel University, Isparta, Turkey \\ Anadolu University, Eskisehir, Turkey
}

\begin{abstract}
Financial literacy has been popular in the global world, is a new field in mathematics education. The study, designed as a document review, aims to review mathematics curriculums of Ontario and Turkey from financial literacy perspective. In these curriculums, it is analysed whether or not financial knowledge and skills are included in the mathematical contents. This is why the interaction between mathematical literacy and financial literacy is mentioned in the study. The analysis is presented using elements of mathematical content, one of the domains of mathematical literacy, declared in PISA, and by elementary level and secondary level. Findings reveal that the curriculum of Ontario has financial literacy knowledge, skills, and behaviours shown in real situations while the curriculum of Turkey includes related financial concepts such as money, shopping and percentage without touching the financial literacy theme.
\end{abstract}

\section{Introduction}

The fundamental aim of education is to prepare students for life. The concept of literacy is capacity of students to apply knowledge and skills, and to analyse, reason and communicate effectively [1]. Recently, there are many sorts of literacy just as mathematical literacy, financial literacy, media literacy, and computer literacy. In education, literacy levels of students are measured in international tests especially at Programme for International Student Assessment (PISA). PISA doesn't consider any curriculums to design test questions. PISA targets students use their problem-solving skills and knowledge in problem situations. In this perspective, PISA leads for curriculums and educational policies of countries. With the addition of financial literacy since 2012, mathematical literacy and financial literacy have emerged as two important sections evaluated in PISA.

Mathematical literacy is identified as a societal need that required quantitative understandings [2]. Mathematical literacy is to find solutions from the mathematical perspective to real problems. Knowledge and skills needed in real life are increasing and complexed. Therefore mathematics is required to solve real life problems in many areas and mathematical literacy is accepted as a prerequisite [3]. One of the areas where mathematics is effective is finance. Mathematics and finance have strong relationships in many concepts like budget, interest, investment, etc.

Financial literacy is to have knowledge about financial concepts, to convert this knowledge to skills and behaviours, and to own confident and motivation for this [4]. Financial literacy is an important and necessary skill for everyone and exposes financial responsibility and freedom needed from early ages. Hence, financial literacy should be integrated into formal education and students should gain financial literacy skills and knowledge.

There are initiatives to consider on financial literacy education. Integration of financial literacy into curriculums is seen valuable and many countries just as Canada, Singapore and The United Kingdom work to integrate financial literacy into their education systems. Mathematical skills are one of the most necessary arguments for financial literacy. Also, both have many common concepts, knowledge, and skills. So, especially at primary and secondary levels, mathematics is seen as the most appropriate course to deal with financial literacy. The review of the mathematics curriculums according to this perspective is seen valuable.

From this point, the aim of the study is to review current mathematics curriculums of two different countries Canada (Ontario) and Turkey from financial literacy perspective. This study attempt to figure out the importance to financial literacy theme of the curriculums and comparing of them. We think that it is important that the relationships between the both areas as well as the perspectives to financial literacy theme of the educational policies of the countries.

\section{Conceptual Framework}

\subsection{Mathematical literacy}

Mathematics is a human accumulation built on needs. The accumulation emerged by looking for solving real life problems, recognizing existing patterns and relationships in nature, reasoning, and developing proofs. Mathematics has served as a key in many intersections that civilization has been forced to solve and explain. Mathematical skills and knowledge are seen as a need to solve real problems and mathematics should be utilized for this. 
According to this, mathematics is a valuable key to solve problems related many various areas. The concept of mathematical literacy also emerges at this point.

Mathematical literacy is a concept that is popular in the mathematics education and is worked for years [5]. Mainly, mathematical literacy is defined as using mathematics in real life. Kilpatrick entitles "mathematical proficiency" instead of mathematical literacy, and refers to mathematical understanding and thinking about real life situations [6]. He refers mathematical literacy beyond mathematics in school. Similarly, The National Council of Teachers of Mathematics (NCTM) identifies mathematical literacy as used mathematical skills and knowledge in various circumstances [2]. Organisation for Economic Co-operation and Development (OECD) focuses on affective skills, and reflects mathematical literacy is to consider mathematics, to see mathematical symbols and mathematical thinking, and to transfer mathematical skills into real life [7]. OECD also points out mathematical literacy as a societal need in modern life. A mathematical literate can utilize mathematics in real life by internalizing mathematical skills and knowledge [8].

To explain mathematical literacy, a couple of models pointed out. Actually, they identify the competencies of a mathematical literate. Pugalee describes mathematical literacy with two concentric circles (see Figure 1). The interaction of these two circles provides the development of mathematical literacy. The broad circle represents the process of mathematical literacy. The inner circle is the factor that influences this process [8].

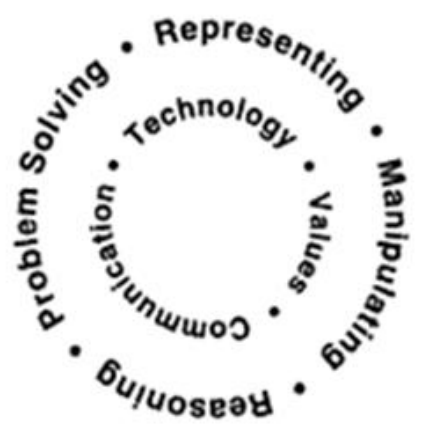

Figure 1. The model of mathematical literacy of Pugalee [8]

The interaction of these two circles provides the development of mathematical literacy. The broad circle represents the process of mathematical literacy. The inner circle is the factor that influences this process [8].

Kilpatrick describes mathematical literacy with five fundamental elements: a) conceptual understanding, b) procedural fluency, c) strategic competence, d) adaptive reasoning, e) productive reasoning [6].
According to these models, mathematical literacy includes many skills as mathematical thinking, mathematical reasoning, problem-solving, utilizing mathematics in real life situations, positive attitude towards mathematics, attaching importance to mathematics.

\subsection{Financial literacy}

Individuals have to balance their incomes and assets for their needs and demands. In that case, people should have a job to earn money and then to invest. In the balancing process, economic situations are occurred such as borrowing, risk, and earning. People usually behaviour like their parents in their financial decisions [9]. Individuals should learn financial knowledge and to earn experience in order to make decision consciously.

Financial literacy is knowledge and understanding of financial concepts, and the skills, and confidence to make effective decisions [10]. Financial literacy is not a specific concept interested in the financial area. On the contrary financial literacy is a need for everyone. A kid should run his/her money weekly, a young should manage his/her school fee and other expenses, even he/she should calculate work time for exes. An adult should make a budget of his/her family and balance their consumptions-investments-incomes. Also, people have to make financial planning for retirement in early years. As known, individual pension systems have been developed and age of retirement has been raised due to increase human life and quality of life standards [11].

From this point of view, individual financial management is an important need for all life. Therefore the concept of financial literacy and financial awareness should be considered.

Generally, a financial literate should have some qualifications:

\section{A financial literate}

- considers the balance of income-outgoing and make a budget.

- analyses advertisements objectively.

- arranges optimum options of saving-investmentspending.

- explains financial decisions to his/her family or other people.

- considers emergency situations and has insurance.

- choices financial aids and has awareness about taxes and bills.

- choices options consciously about credit, credit card, interest rate.

- has confidence in his/her financial decisions.

- knows fundamental financial concepts and national-international financial circumstance $[11,12$, $13,14,15]$. The qualifications are more. Remarkable features in these criteria are effective communication, 
sufficient knowledge, and to transfer knowledge and skills to behaviours.

Financial literacy theme has an increasing popularity in related areas like education as well as it is studied in economy and finance. Financial literacy is a phenomenon that exposes financial responsibility and freedom needed from early ages [14]. So financial literacy should be included in formal education and students should be able to access financial literacy [15]. Many countries such as Australia, Brazil, Canada, Singapore, The United States, and The United Kingdom have begun to integrate financial literacy into their education systems with led studies conducted by Organisation for Economic Cooperation and Development (OECD) since the 2000s [3]. Similarly, some European countries such as Denmark, Estonia, and Ireland have worked on the financial literacy education [12]. Financial literacy is also a separate theme in the economy area and is a separate course many countries such as Canada, US, and Australia, however, it should be integrated into related courses like mathematics.

Ontario (Canada) is one of the countries which carried out the process of integration financial literacy in their curriculums. In the process started by 2010 , financial literacy is integrated into many related curriculums including mathematics [13, 17]. The monitoring of the process is keeping. A report was published to process named "A Sound Investment Financial Literacy Education in Ontario Schools" (Figure 2). Ontario is a phenomenon in financial literacy education initiatives because of their curriculums, detailed studies, and reports on financial literacy. So in our study, a comparison between Ontario and Turkey which is the country of the researchers is seen valuable.

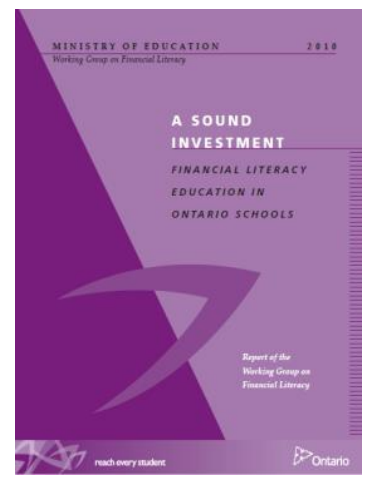

Figure 2. The report of the financial literacy project of Ontario [13]

\section{Methodology}

In this study, the position of financial literacy theme in the current mathematics curriculums of Ontario (Canada) (CoO) and Turkey (CoT) by elementary and secondary level is analysed. Turkey has the new curriculums announced in 2017 while the Ontario mathematics curriculums were revised in 2011.

This study is designed as a document review. The PISA perspective towards literacy is considered in the review. PISA handles the framework of literacy in three main domain: a) content, b) process and c) context. In the PISA questions of mathematical literacy, processes which provide to display mathematical skills are emerged using mathematical concepts in the various contexts. The mathematical contents include

a) quantity,

b) change and relationships,

c) space and shape,

d) uncertainty and data.

In this study, the mathematical contents on the financial contexts are considered and common processes that include target acquisitions are viewed. The curriculums are compared according to mathematical contents, which concepts are in the curriculums, how is the deep of the concept and their relationships with mathematical concepts and heads, what is the circumstance in the same heads.

There are a couple of tables to compare of the curriculums in findings. Also, some pictures are added that expose curriculums details. It is expected to present the intensity of financial knowledge and skills, how financial concepts are processed, and the fundamental perspective to financial literacy of the curriculums.

\section{Findings}

\subsection{Findings for elementary level}

\section{a) Quantity}

It is seen that introduction banknotes and coins, simple operations, basic proportional reasoning and the using percentile in both of them. Ontario aims to teach numbers by money whereas Turkey focuses on the concept of percentile and calculating. In the content of quantity, Ontario focuses on proportional reasoning and comparing in financial problems. It is showed in Figure 3.

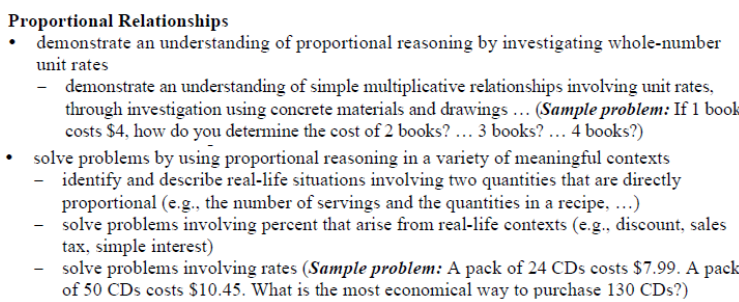

Figure 3. Proportional relationships in the Ontario math curriculums [20] 
Table 1. The comparison of the elementary curriculums for mathematical content: Quantity

\begin{tabular}{|l|l|}
\hline & - using the money to understanding numbers. \\
& - reading, writing, representing and comparing \\
money and relating whole numbers, decimal \\
numbers and simple fractions. \\
$0_{0}$ & $\begin{array}{l}\text { - making simulated purchases, simple } \\
\text { calculations and operations, simple multiplicative } \\
\text { relationships } \\
\text { - solving problem using percent about price, } \\
\text { taxes, discount, simple interest and marketing } \\
\text { campaign }\end{array}$ \\
\hline \multirow{5}{*}{} & $\begin{array}{l}\text { - determining moneys (banknote, coins) } \\
\text { - simple shopping, gathering pocket money for } \\
\text { weekly } \\
\text { - percent of discount and raising }\end{array}$ \\
\hline
\end{tabular}

\section{b) Change and relationships}

In second content, change and relationships, in Ontario, it is noticed the desire to construct simple equations and to model of real life situations about finance.

Table 2. The comparison of the elementary curriculums for mathematical content: Change and relationships

\begin{tabular}{|c|c|}
\hline $\begin{array}{l}0 \\
0 \\
0\end{array}$ & $\begin{array}{l}\text { - variables as changing quantities, given equations } \\
\text { with symbols that describe relationships involving } \\
\text { simple rates. } \\
C=3 \times n \text { and } 3 \times n=C \text { both represent the } \\
\text { relationship between the total cost }(C) \text {, in dollars, } \\
\text { and the number of sandwiches purchased }(n) \text {, when } \\
\text { each sandwich costs } \$ 3 \text { ) } \\
\text { - Using algebra and modelling in financial real life } \\
\text { situations }\end{array}$ \\
\hline ن & \\
\hline
\end{tabular}

\section{c) Space and shape}

Table 3. The comparison of the elementary curriculums for mathematical content: Space and shape

\begin{tabular}{|c|l|}
\hline & $\begin{array}{l}\text { - solving problems that require conversion } \\
\text { between metric units of measure }\end{array}$ \\
8 & $\begin{array}{l}\text { Sample problem: At Andrew's Deli, cheese is on } \\
\text { sale for \$13 for one kilogram. How much would it } \\
\text { cost to purchase 150 g of cheese?) }\end{array}$ \\
\hline & \\
\hline
\end{tabular}

In content of space and shape, Ontario focuses on converting metric units of measure. It is a practical skill used frequently in real life.

\section{d) Uncertainty and data}

In the final content for elementary level, uncertainty and data, it is seen that both of them use various tools to analyse data.

Table 4. The comparison of the elementary curriculums for mathematical content: Uncertainty and data

\begin{tabular}{|c|c|}
\hline O̊ & $\begin{array}{l}\text { - Reading and interpreting conclusions data about } \\
\text { financial context presented in charts, tables, and } \\
\text { graphs. } \\
\text { - Determining, through investigation, the effect on } \\
\text { a measure of central tendency (mean, median, and } \\
\text { mode) }\end{array}$ \\
\hline 官 & $\begin{array}{l}\text { - Using various tools for organizations of data } \\
\text { relating financial literacy. }\end{array}$ \\
\hline
\end{tabular}

\subsection{Findings for secondary level}

\section{a) Quantity}

The other side, in secondary level, in this content, it is seen that Turkey just focuses on calculating. The absence of simple and compound interest, an important concept in the financial area, is a major deficiency for Turkey.

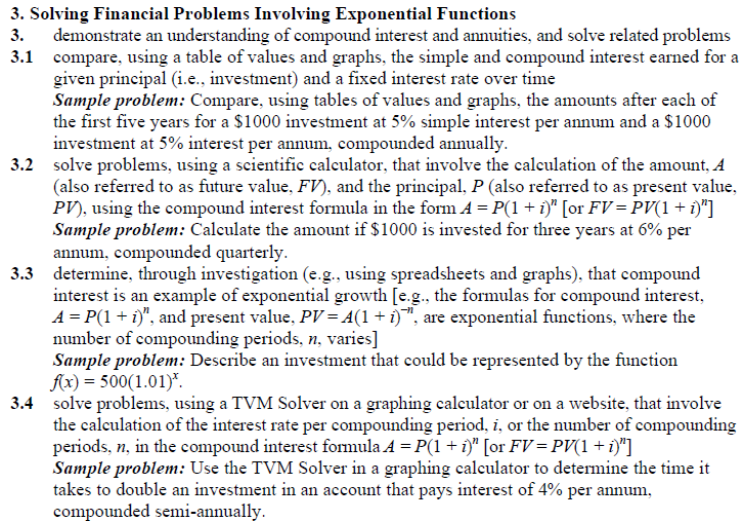

Figure 4. The consideration on interest of the Ontario math curriculum [20]

Ontario focuses on understanding fundamental financial concepts including interest as well as they care generally to select the best or better options in financial situations. Figure 4 shows the consideration of interest in the Ontario Curriculums. 
Table 5. The comparison of the secondary curriculums for mathematical content: Quantity

\begin{tabular}{|c|c|}
\hline $\begin{array}{l}0 \\
0 \\
0\end{array}$ & $\begin{array}{l}\text { - comparison of renting and buying } \\
\text { - personal finance } \\
\text { - comparing simple and compound interest, } \\
\text { - solving problems involving compound interest } \\
\text { - comparison services (as credits) available from } \\
\text { financial institutions, and solving problems on } \\
\text { credits. }\end{array}$ \\
\hline î & - calculating bills and other payments \\
\hline
\end{tabular}

\section{b) Change and relationships}

It is seen here (see Table 6), Ontario would rather take care of understanding mathematical representations and mathematical modelling than calculating. Here, there is an effort to integrate financial knowledge and skills to all headings including the functions and the series even the derivatives. Also, there are the analysis the formula of compound interest and the extremes points of financial situations by derivatives.

Table 6. The comparison of the curriculums for secondary level for content: Change and relationships

- constructing an equation to represent payment a monthly cellphone, registration fee, represent of salary etc.

- modelling algebraically \& graphically in real situations.

relating compound interest to exponential growth, modelling the cost of paint for a rectangle wall

- making connections between sequences, series, and financial applications and calculations.

- solving problems involving the various

functions

- the composition functions

the time when the car is running most

economically during a trip

-the derivatives

identify the periods of inflation and deflation, and the time at which the maximum rate of inflation occurred by derivatives.

-the polinomial functions.

recognize that the compound interest formula,

$A=P(1+i)^{n}$ using a variety of tools and

strategies when different variables in a formula are set as constants.

-using exponantial functions for real situations

compound interest for borrowing, how much might future population increase water use?

\section{c) Space and shape}

In the curriculums of Ontario, it is the fundamental issue, how can we use mathematical knowledge and skills in financial situations. The similar questions are involved in PISA as well. As you see here, you need to make financial planning even to paint a wall.

Table 7. The comparison of the secondary curriculums for mathematical content: Space and shape

\begin{tabular}{|l|l|}
\hline & - Payment by area \\
& How much is the painting cost for a rectangular \\
& wall? \\
8 & $*$ How many square meters of the rectangular \\
U & $\begin{array}{l}\text { area? } \\
\text { * How many box of it is required for a square } \\
\text { meter? } \\
\text { * Which box is the best choice? Small or large? }\end{array}$ \\
\hline பे & \\
\hline
\end{tabular}

\section{d) Uncertainty and data}

Table 8: The comparison of the secondary curriculums for mathematical content: Uncertainty and data

\begin{tabular}{|c|c|}
\hline ن & $\begin{array}{l}\text { - organisation of data for analysis } \\
\text { collection of working times data in various } \\
\text { countries by convenient methods and analysing } \\
\text { - working with one-variable data to compare two } \\
\text { or more } \\
\text { sets using measures of central tendency and } \\
\text { measures of spread } \\
\text { *comparing the lifetime of an economy light bulb } \\
\text { and a long-life light bulb } \\
\text { - analysing two-variable data by graphs and } \\
\text { interpreting } \\
\text { - comparing services (as credits) available from } \\
\text { financial institutions, and solving problems on } \\
\text { credits. } \\
\text { - using probability to make financial planning } \\
\text { the effects of cancelled hotel reservations on the } \\
\text { earning } \\
\text { - proper interpretation data of World population } \\
\text { and World economies. } \\
\text { - describing examples of indices used by the media } \\
\text { consumer price index, S\&P,... } \\
\text { - proper understanding graphs and data in real life. } \\
\text { * "Big Increase in Profits". Suggest reasons why } \\
\text { this headline may or may not be true. } \\
\text { - understanding of the applications of data } \\
\text { management } \\
\text { used by the media and the advertising industry and } \\
\text { in various occupations }\end{array}$ \\
\hline 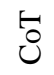 & \\
\hline
\end{tabular}


In the content of uncertainty and data, it is seen Ontario works on the analysis of one variable and two variable data. Especially, they consider on comparing conditions and interpreting of data. Additionally, you can use probability when you make a financial planning by cancelled reservations for a hotel. To know the financial world and financial landscape is very important for financial literacy. The curriculum of Ontario considers these concepts. Here there is interpretation of world population and economy, the definition of indices used by the media, such as Standard and Poor's.

\subsection{Findings for workplace sections}

In both countries, another program is used to prepare students who don't consider university for their life. In these curriculums, there are similar headings, such as travel costs, shopping, taxes, and bills. Also, Ontario handles other concepts, such as probability and measurement about finance. For example, how many are people in a crowd? designing and budgeting for a household improvement, the probability of winning the gamble.

Table 9. The comparison of the curriculums for secondary level in 'workplace'-'everyday life' sections

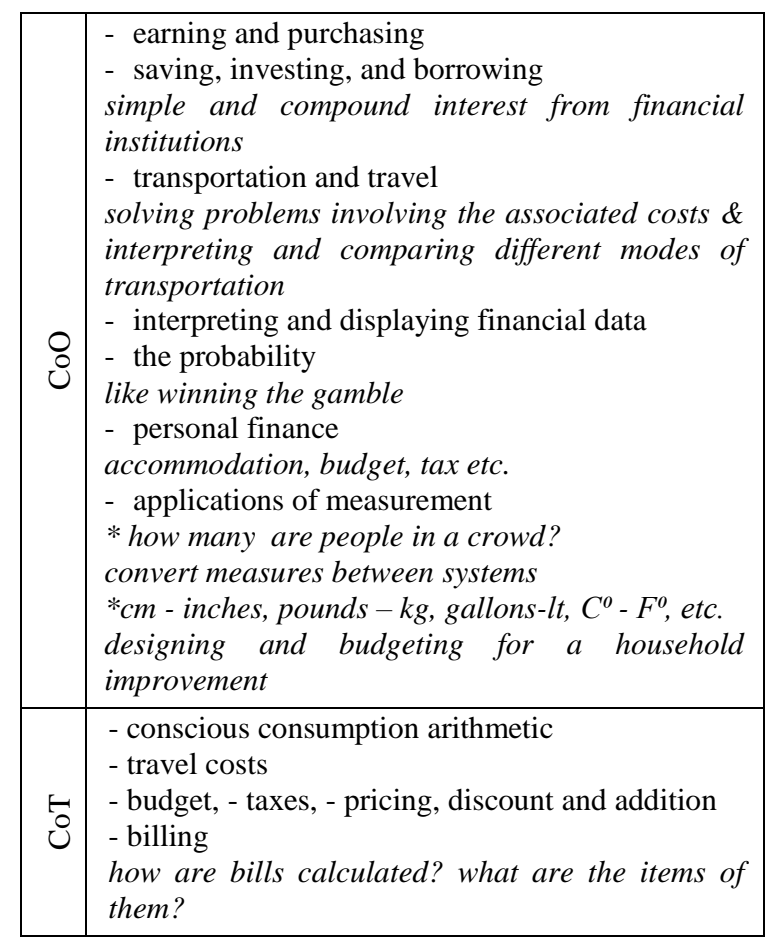

\section{Discussion}

It is seen that in the curriculum of Ontario, there are lots of relationships between financial and mathematical contents. Some concepts such as interest are dealt with in almost all grades. It shows a harmony that is a fundamental dynamic of a design of curricula. Also, in Ontario, mathematics education and financial literacy education promote each other however Turkey uses financial contexts only to gain mathematical skills.

In the curriculum of Ontario, it is seen that financial contents are used intensely, conceptual relations and reasoning are asked from students. Ontario curriculum has many headings financially and also, many real life situations are added into the curriculums. On the other hand, in the curriculum of Turkey, even the fundamental frames such as the interest and investment are not placed. There are some knowledge and skills centred on the percentage and calculating but these are not sufficient.

As shown in findings, in both countries, another program is used to prepare students who don't consider university for their life. Turkey executes this project since 2013. Though this is a simplified program, it has more financial contents than the general curriculum but both of the curriculums of Turkey don't refer financial literacy clearly.

As an overview for all, the theme of financial literacy is considered in Ontario as one of the most important basics of the curriculum which makes students feel that and this curriculum can be considered a good model to the integration of financial literacy. Ontario curriculum has organised this integration according to three themes: real life, PISA, and dynamics of financial literacy [13]. The curriculums provided that students can reflect their financial knowledge and skills in real life. This is already to be a financial literate. Also, it is shown in Ontario maths curriculum how students can use mathematics in solving problems in the financial area such as painting wall or monthly cell phone planning. In this curriculum it is possible to see what the definition of literacy means for real life and how the financial literacy education can integrate a curriculum. Similarly, it can be said that the curriculum of Ontario has harmony with aims and contents of PISA. The Ontario math curriculums and PISA have utilized similar questions and heads. From this point of view, PISA is accepted as a reference for some countries' curricula. The effective presentation of data and correct interpretation of data are skills necessary current life. The Ontario curriculum focus on both. Besides, it appears that Ontario curriculum has gains and content to educate people on tools and realities of the local and global financial world. Moreover, the realities of the financial world and to know financial landscape are a need for effective financial literacy education.

\section{Conclusion}

It will be useful that mathematics curriculums should be handled focusing on real life situations within the framework of mathematical literacy and financial literacy. And also, countries which consider 
the integration should analyse successful projects like Ontario. It is considered the concept of financial literacy risen in the global world will be more popular through PISA and other effects. The reports of PISA should be considered in the integration of financial literacy education into curriculums of subjects like mathematics. Also, it is considered valuable to uncover the interaction between mathematics and finance because mathematical knowledge and skills are needed for financial competencies. In that case, in studies on the interaction between both areas, the competencies of both mathematical literacy and financial literacy should be handled. In this context, the studies in education that show the frame of financial literacy and interaction between mathematical and financial literacy are needed.

\section{References}

[1] OECD, (2016). 'The PISA 2015 Assessment Framework: Mathematics, Reading, Science and Problem Solving Knowledge and Skills, PISA', OECD Publishing.

[2] NCTM, (1989). 'Curriculum and Evaluation Standards for School Mathematics', Reston, VA.

[3] OECD. (2016). 'Financial Literacy Framework, PISA 2012 Assessment and Analytical Framework: Mathematics, Reading, Science, Problem Solving and Financial Literacy', OECD Publishing, Paris.

[4] OECD, (2016). 'Financial Literacy Framework, PISA 2012 Assessment and Analytical Framework: Mathematics, Reading, Science, Problem Solving and Financial Literacy', OECD Publishing, Paris.

[5] Niss, M., and Jablonka, E., (2014). 'Mathematical literacy', Encyclopedia of mathematics education pp. 391396. Springer Netherlands.

[6] Kilpatrick, J., (2001). 'Understanding Mathematical Literacy: The Contribution of Research' Educational Studies in Mathematics, 47.1, 2001, pp. 101-116.

[7] OECD, (2016) 'Financial Literacy Framework, PISA 2012 Assessment and Analytical Framework: Mathematics, Reading, Science, Problem Solving and Financial Literacy', OECD Publishing, Paris.

[8] Pugalee, D.K., (1999). 'Constructing A Model of Mathematical Literacy', the Clearing House 73.1, pp.19-22.

[9] Lusardi, A., Mitchell, O. S., and Curto, V., (2010). 'Financial literacy among the young', Journal of Consumer Affairs, 44(2), pp. 358-380.

[10] Lusardi, A., (2012) 'Numeracy, Financial Literacy and Financial Decision-Making', National Bureau of Economic Research.

[11] Lusardi, A., and Mitchell, O. S., (2008). 'How Much Do People Know About Economics and Finance. Financial
Illiteracy and the Importance of Financial Education', Policy Brief: Michigan Center for Retirement Research.

[12] OECD, (2016). Financial Education in Europe: Trends and Recent Developments, OECD Publishing, Paris. http://dx.doi.org/10.1787/9789264254855-en

[13] Ministry of Education Ontario, (2010). 'A sound Investment Financial Literacy Education in Ontario Schools', Ministry of Education Ontario.

[14] Xiao, J. J., Ahn, S. Y., Serido, J., and Shim, S., (2014). 'Earlier financial literacy and later financial behaviour of college students', International Journal of Consumer Studies, 38(6), pp. 593-601.

[15] Davies, P., (2015). 'Towards a framework for financial literacy in the context of democracy', Journal of Curriculum Studies, 47(2), pp. 300-316.

[16] Aprea, C., Wuttke, E., Breuer, K., Koh, N. K., Davies, P., Greimel-Fuhrmann, B., and Lopus, J. S., (Eds.). (2016). 'International Handbook of Financial Literacy', Springer.

[17] Orton, L., (2007). 'Financial Literacy: Lessons from International Experience', Canadian Policy Research Networks, Ontario.

[18] Milli Eğitim Bakanlığı, (2017). 'Matematik dersi Öğretim programı (İlkokul ve ortaokul 1-8.sınıflar)', http://mufredat.meb.gov.tr/ProgramDetay.aspx?PID=191 (27.08.2017)

[19] Milli Eğitim Bakanlığı, (2017). 'Ortaöğretim Matematik Dersi Öğretim Programı', http://mufredat. meb.gov.tr/ProgramDetay.aspx?PID=179 (27.08.2017)

[20] Ministry of Education Ontario, (2011). 'Financial Literacy Scope and Sequence of Expectations. The Ontario Curriculums', Ministry of Education Ontario. 